\title{
ELECTRIC POWER GENERATION IN ONTARIO ON SYSTEMS OF HYDROELECTRIC POWER COMMISSION $\dagger$
}

\author{
BY ARTHUR H. HULL
}

THE Province of Ontario is the largest and most populous
of the Provinces in the Dominion of Canada, having an area of 407,262 square miles and a population (census 1911) of $2,523,274$. Ontario's population is about 35 per cent of the total of Canada's population, and its area is 10.9 per cent of the total area of the Dominion. Ten per cent of its area is water.

Ontario has developed into the greatest manufacturing Province in Canada and as there are no coal deposits in the Province, its abundant water power resources are being more and more utilized to furnish the power required for its varied and increasing industrial development. Other fuels, such as natural gas and petroleum are found in the southern part of the Province, gas along the north shore of Lake Erie and petroleum near Sarnia. The natural gas supply, however, is insufficient for present purposes and the quantity of petroleum produced does not begin to meet the needs of the Province. The demand for electric power has increased during the past ten years to such an extent, that, with the war industries in operation, it became necessary to impose restrictions on private and municipal consumers in order to provide the power required by the war industries. The great saving in coal effected by the use of electric power in Ontario's industries is one of the most important aspects of the electric power situation, and further great savings can be, and will be before long, brought about by the electrification of the steam railroads.

Mr. H. G. Acres* in a monograph on Water Powers of the Province of Ontario, written in 1915, gives the following sum-

\footnotetext{
*Hydraulic Engineer, Hydroelectric Power Commission.

†The illustrations for this paper have been omitted from these advance copies as they were not supplied in time for publication. They will be shown at the meeting by means of lantern slides.
} 
mation of water power capable of development, and of water power already developed in the Province.

\begin{tabular}{|c|c|c|}
\hline Division & Potentiality & Developed. \\
\hline Ottawa River \& Tributaries & 688,000 h.p. & 71,000 h.p. \\
\hline Great Lakes Tributaries............ & 446,000 “ & 137,000 “ \\
\hline Hudson Bay Slope................ & 250,000 & 22,000 \\
\hline James Bay Slope ............. & $1,500,000$ & 70,000 \\
\hline International Boundary Rivers... . & $2,045,000$ & 462,000 \\
\hline
\end{tabular}

Of the above total for power developed, about 69,000 horse power is used in pulp and paper manufacture, about 59,000 horse power is used as hydraulic power directly applied, and the balance 574,000 horse power is converted into electric energy for light and power.

This paper will deal only with the generation of electric power by the Hydro Electric Power Commission of Ontario which is now the largest producer and distributer of electric energy in the Province.

The Hydro Electric Power Commission of Ontario, which will be referred to hereafter as the Commission, was formed by the Ontario Government in 1906, and first furnished power over its 110,000-volt lines from Niagara Falls in October 1910, the power being purchased from the Ontario Power Company of Niagara Falls, Ontario. It was not until August 1st, 1917, that the Commission obtained direct control of the generation of power at Niagara Falls, through the Ontario Power Company, but in other parts of the Province, the Commission had started to develop its own power by constructing a hydroelectric plant at Eugenia Falls on the Beaver River near Flesherton, which was put into operation in November 1915, and one at Wasdell's Falls on the Severn River which was started in service in October 1914. In 1914 the Commission acquired by purchase the Simcoe Railway and Power Company, whose generating station at Big Chute on the Severn River had previously supplied power under contract to the Commission's Severn System, supplying the district around the southern part of Georgian Bay. In March 1916 the Government of Ontario purchased the entire holdings of the Electric Power Company which, through subsidiary Companies, was generating power on the South River near Nipissing, on the Otanabee River 


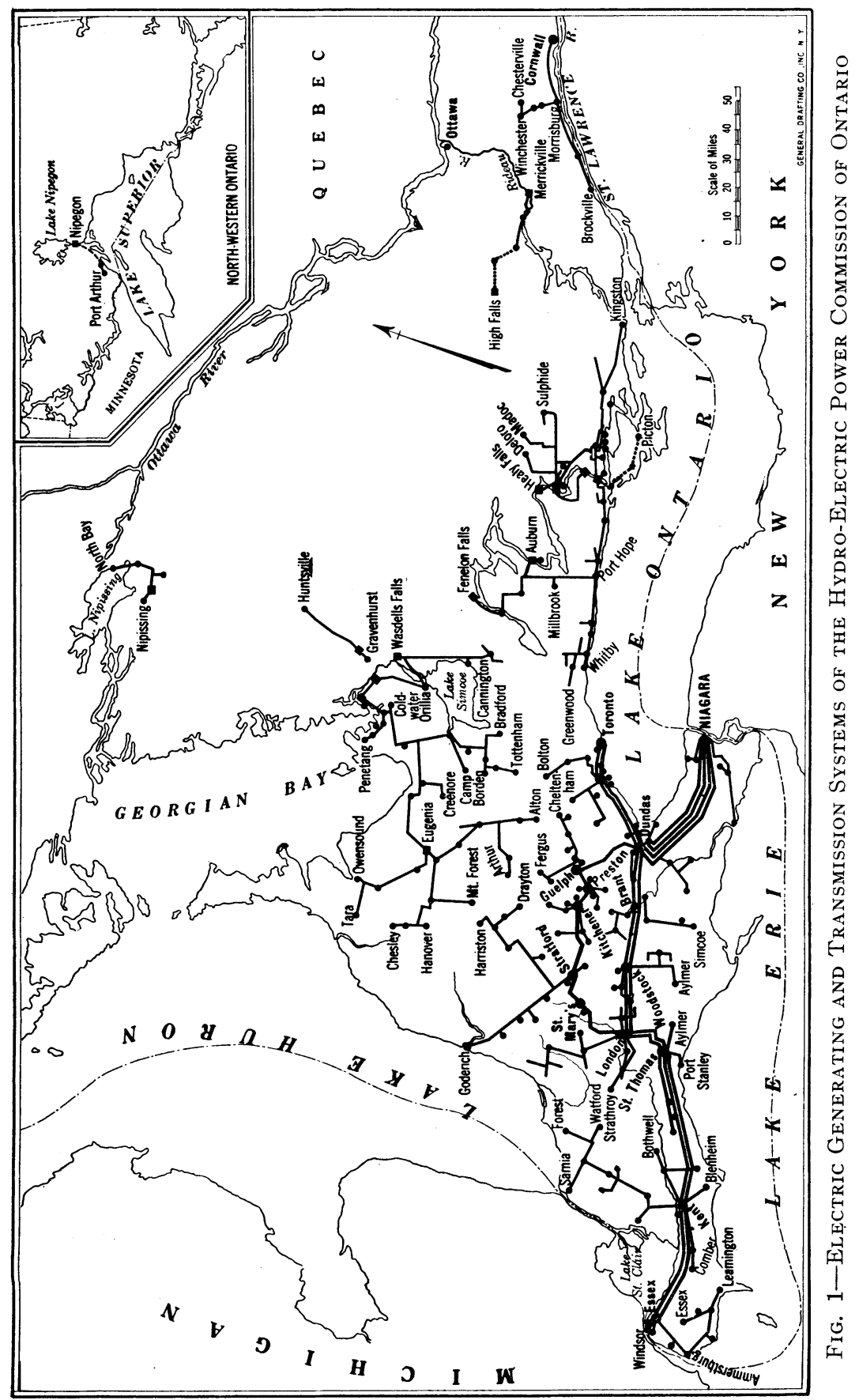


at Peterboro, and on Trent River at Healy Falls, Frankford, Campbellford, and Trenton. The operation of the equipments thus acquired was placed in charge of the Commission in June 1916.

The various areas in the Province served by the Commission are designated by Systems as follows

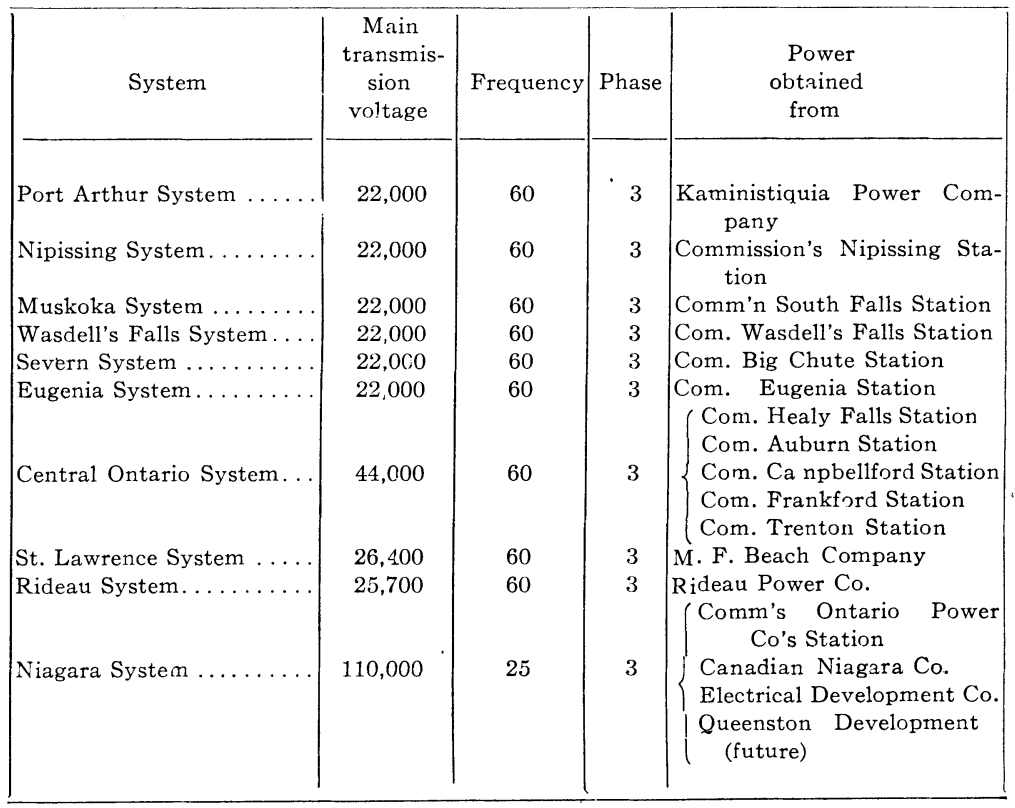

\section{Port Arthur System}

In the Port Arthur System, power is purchased at 22,000 volts, three phase, 60 cycles from the Kaministiquia Power Co., and is delivered to the City of Port Arthur at 22,000 and at 2200 volts, part being transformed in the Commission's Transforming Station in Port Arthur, containing two banks of transformers, each consisting of three $750-\mathrm{kv}-\mathrm{a}$. units connected star-delta with neutral ungrounded.

The first delivery of power was made on December 21st, 1910. The demand has been steadily increasing and in order to take care of the future requirements, the Commission now propose to construct a hydroelectric station on the Nipigon River at Cameron's Pool, about 80 miles from Port Arthur, which will have an ultimate capacity of about 50,000 horse power. The engineering work is now under way for this development. It 
is proposed to transmit the power at 110,000 volts, three phase, 60 cycles, to Port Arthur. Three other power sites on this same river, when developed, will, together with the Cameron's Pool site, give a total of 150,000 horse power. The needs of the Port Arthur district should, therefore, be amply provided for, but if additional power should be required for this district, another site is capable of development at Silver Falls on the Kaministiquia River about 25 miles from Fort Willian where with a 350 -ft. head a total of 25,000 horse power can be developed. At the present time the electric energy supplied at Port Arthur is used for operation of the street railway, for public and ilomestic lighting, and for large grain elevators, ship yards, coal docks: and miscellaneous industrial purposes.

\section{Nipissing System}

The Nipissing System, formerly controlled by the Nijissing. Power Company, comprises a generating station on the South River near Nipissing Village, sub-stations in Callander, Powassan and North Bay. The Transmission system comprises 26.5 miles of 22,000-volt, three-phase, circuit on wooden poles. The generating station contains two $450-\mathrm{kw}$. three-phase 2200 volt 60 -cycle 450 -rev. per min., horizontal generators with 12.5-kw. 125-volt direct-connected exciters, each unit direct coupled to a water wheel of 925 b.h.p. at $86 \mathrm{ft}$. head. A 37.5-k.w. 125 -volt motor-driven exciter is also provided. Three $300 \cdot \mathrm{kv} \cdot \mathrm{a}$, $2200 / 22000$-volt single-phase water-cooled transformers connected delta-delta are installed, with one 22,000-volt outgoing feeder.

Water for this plant is taken from the South River through an open canal $900 \mathrm{ft}$. long, then through a wood stave pipe $6 \mathrm{ft}$. diameter $2300 \mathrm{ft}$. long to a differential surge tank 72.5 feet high, close to the power house, a steel penstock connecting thence to the turbines. The storage pond has an area of abcut 100 acres and the drainage area of the river is about 350 square miles.

Provision was made for extension, and by additional storage works, it is possible to increase the capacity to 2500 horse power.

\section{Muskoka System}

The power house on the south branch of the Muskoka River at Muskoka Village was formerly owned by the Municipality of Gravenhurst and was taken over by the Commission in the 
latter part of 1915 , and has been remodelled and enlarged, and now supplies power over a single circuit 22,000-volt, threephase, 60-cycle line about 26 miles long to Huntsville, and at 6600 volts three phase, 60 cycles, to the Municipality of Gravenhurst over the Municipality's line.

The equipment in this station now comprises one $450-\mathrm{kv}-\mathrm{a}$., three-phase, 6600-volt, 720-rev. per min., 60-cycle generator, direct connected to a 500 b.h.p. turbine; one $750-\mathrm{kv}-\mathrm{a}$. similar 720 -rev. per min. generator, direct connected to a 1000 b.h.p. turbine; one bank of three $400-\mathrm{kv}-\mathrm{a} ., 6600 / 22,000$-volt transformers connected delta-delta; double low-tension bus, and single high-tension tus. Four outgoing 6600-volt feeders are

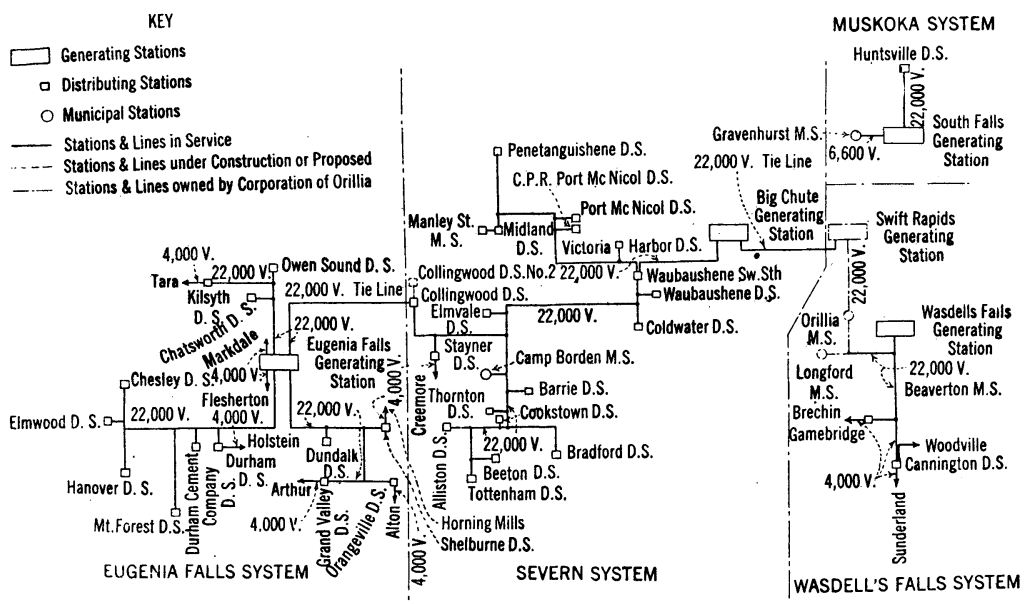

Fig. 2-Diagram of Eugenia Falls, Severn, Wasdell's Falls, and Muskoka Systems-60 Cycles

provided, two feeding to Gravenhurst and two for future use. One 22,000-volt feeder leaves the station to supply Huntsville. Provision is made in the existing building for a second hightension feeder.

When this station was taken over by the Commission, only one 450-kv-a. generator was installed. The station was remodelled and enlarged for the larger unit mentioned above, and provision was made for the extension of the building at a future date and for the replacing of existing units so that, when future load conditions require it, there will ultimately be three $1500-\mathrm{kv}-\mathrm{a}$. generators with a turbine capacity of 6000 horse power installed. 
The present excitation at this plant is provided by, a turbinedriven exciter for the $450-\mathrm{kv}$-a. unit, a motor-driven exciter for the 750-kv-a. unit, which also has a belted exciter for emergency use, which is so arranged that it may excite either generator.

The hydraulic head at this plant is $102 \mathrm{ft}$. The water is conducted through one steel and one wood stave pipe, each $946 \mathrm{ft}$. long to the turbines.

\section{Wasdell's Falls System}

This system comprises a hydraulic generating station on the Severn River at Wasdells' Falls near Severn Bridge, and substations at Beaverton and Cannington. Power is transmitted to Beaverton and Cannington over a single-circuit steel-conductor line at 22,000 volts, three phase 60 cycles, and over a single circuit aluminum tie line at the same voltage to the Commission's Severn System, connecting at Longford with the Town of Orillia 22,000-volt lines from Longford via Orillia to the Big Chute generating station.

The generating station which was constructed by the Commission in 1914 is interesting on account of the low hydraulic head. The normal head is $12 \mathrm{ft}$., but variations from 9 to 15 ft. occur. The equipment consists of two $400-\mathrm{kv}-\mathrm{a}$., 90 -rev. per min., vertical type 60 -cycles, three-phase, 2300 -volt generators connected through flexible couplings to turbines rated at 600 horse power at 100 per cent gate opening with 12 -ft. head. Two exciters, one $20-\mathrm{kw}$. turbine-driven, and one $30-\mathrm{kw}$. motor-driven are provided. Two banks of transformers, each consisting of three $2200 / 22,000$-volt $150-\mathrm{kv}$-a. units connected delta-delta are installed. Two outgoing 22,000-volt lines were provided.

There are in this system, 37 miles of 22,000 -volt circuit and 23 miles of 4000 -volt circuits from the two sub-stations.

\section{Severn System}

This system comprises a hydraulic generating station on Severn River at Big Chute with substations as shown in the diagram.

The generating station as originally built in 1909 by the Simcoe Railway and Power Company contained three 900kv-a., three-phase, 2200-volt, 60-cycle, 300-rev. per min., horizontal-shaft generators direct connected to turbines each 
rated at 1300 horse power under $56-\mathrm{ft}$. head; two $100-\mathrm{kw}$. 580-rev. per min., 125-volt exciters direct connected to 200-h.p. turbines; two transformer banks each consisting of three $600-\mathrm{kv}$-a., 2200/25,000-volt water-cooled transformers connected delta-delta, with two outgoing 25,000-volt lines. An extension to the building has been made by the Commission during the past year, and there is now being installed one $1600-\mathrm{kv}-\mathrm{a}$., three-phase, 60-cycle, 2200-volt 300-rev. per min. horizontal generator direct-connected to a 2300-h. p. turbine. The switching equipment is being rearranged to provide a double hightension bus for greater flexibility in operation. Space is left for a third bank of transformers, and for two future 22,000-volt line equipments. A double low-tension bus is installed. All power is transmitted at 22,000 volts, three phase, over four lines.

An interesting feature of the transmisssion lines of this system is the long spans across Matchedash Bay at Waubaushene, one being $1135 \mathrm{ft}$. long and one $858 \mathrm{ft}$. long. The west shore tower is $175 \mathrm{ft}$. high, the middle and east shore towers are 88 ft. high. No. 00 B. \& S. 19-strand copper conductors are used on these spans.

The water is taken from the river through a canal $500 \mathrm{ft}$. long to the head works and then through two steel penstocks $170 \mathrm{ft}$. long to the turbines.

\section{Eugenia System}

This system obtains power from a hydraulic generating station constructed by the Commission at Eugenia on the Beaver River which was placed in service in November 1915. Extensions are now almost completed to provide double the output. This development is one of the most interesting in Ontario, and has the distinction of having with one exception, the highest hydraulic head of any plant in Canada, being $552 \mathrm{ft}$. gross. It is also one of the highest heads in the world using reaction wheels.

The first installation consisted of two 2250-h.p. turbines each direct connected to $1410-\mathrm{kv}-\mathrm{a}$., three-phase, 4000 -volt, 60 -cycle 900 -rev. per min., horizontal-shaft generators having neutral grounded without resistance; one bank of three 900$\mathrm{kv}$-a., 4000/25,000-volt transformers connected delta-delta, single high-tension and low-tension busses, two outgoing 25,000volt feeders and two 4000 -volt feeders, one each to Markdale and Flesherton. The extensions cover enlargement of the 
PLATE II.

A. I. E. E.

VOL. XXXVIII, NO. 1

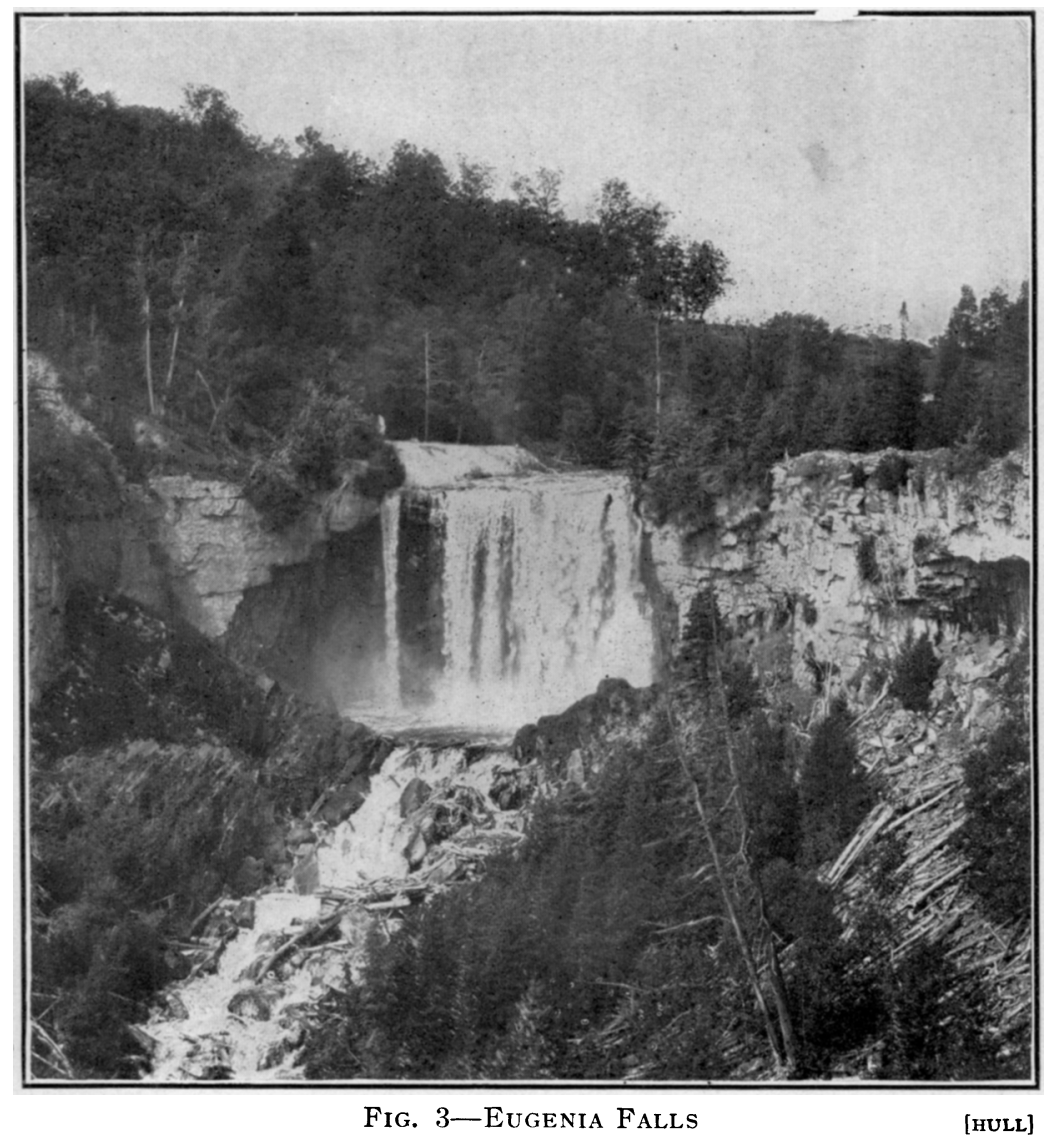



building to accommodate two additional generating units, one of which is now being installed, and for double high-tension and low-tension busses, and for six 25,000-volt feeders. The new unit consists of a $2810-\mathrm{kv}$-a., three-phase, 60-cycle, 720rev. per min. horizontal maximum-rated generator direct connected to a 4000-h. p. turbine. Each generator has a direct-connected 125-volt exciter of sufficient capacity to excite two generators.

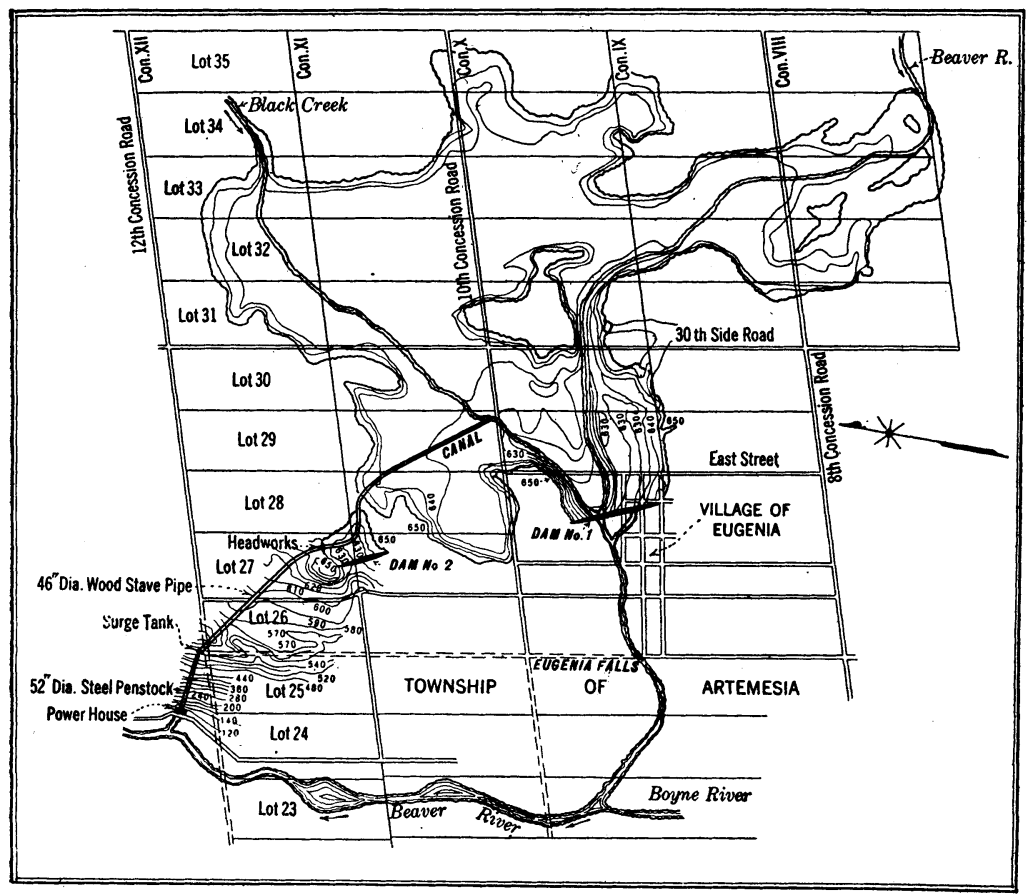

Fig. 4-Eugenia Falls-General Plan of Power Development on Beaver River

The success of the development depended upon the storage of the water of the Beaver River and for this purpose two large storage dams were constructed as shown on accompanying plan. From the head works, a wood stave pipe 46 in. in diameter conducts the water $3400 \mathrm{ft}$. to the Johnson differential surge tank which is $105 \mathrm{ft}$. high. From this tank a 52 -in. diameter steel pipe is carried $1550 \mathrm{ft}$. to the power house, which is a brick building $69 \mathrm{ft}$. wide, $112 \mathrm{ft}$. long and $34 \mathrm{ft}$. high above the generator room floor. Actual tests made at this station 
after the first installation was completed in 1915 gave an overall full load efficiency of 80 per cent which shows how carefully the design was worked out.

Additional power for the Eugenia System will be obtained, when required, by the construction of further water storage systems and of a second pipe line at the Eugenia Falls development and the installation of a fourth unit, also by the construction of a station on the Saugeen River near Lake Huron which operating in parallel with the Eugenia Station will make available a total output for the system of $15,000 \mathrm{~h}$. p.

The Eugenia System comprises 245 miles of 22,000 -volt circuit (176 miles of lines) supplying substations at the points shown on accompanying diagram, and 50 miles of 4000 -volt circuits. This system is connected to the Severn System by means of a single-circuit three-phase tie line from the Eugenia generating station to Collingwood, a distance of 24 miles.

By means of this tie line and the tie line from Wasdells' Falls to Big Chute mentioned above, the Eugenia, Severn, and Wasdells' systems are paralleled. The generating station of the Town of Orillia on the Severn River at Swift Rapids near Big Chute is also connected into the Severn system.

\section{Central Ontario System}

Five main generating stations, one on the Otonabee River and four on the Trent River, all operating in parallel, supply this System. These are now fully loaded and plans are being prepared for new stations near Campbellford to provide additional power. The five exciting stations were built by the subsidiary companies of the Electric Power Company. Immediately after the operation of this system was placed under the Commission by the Ontario Government, arrangements were made to install a new unit in the Healy Falls generating station and work on the same is now nearing completion.

The following table gives the data relative to the existing developments, all generators being three-phase, 60 cycles, with 25 per cent overload guarantees:

In addition to the above stations, a $1000-\mathrm{kv}-\mathrm{a}$., three-phase, 60 -cycle, 120-rev. per min. horizontal generator owned by the Town of Campbellford in its generating station, a short distance north of the Campbellford station, delivers its output to the 2400 -volt bus in this station. Also at Fenelon Falls, a small generating station is operated, containing two $400-\mathrm{kw}$., 600 -volt, 


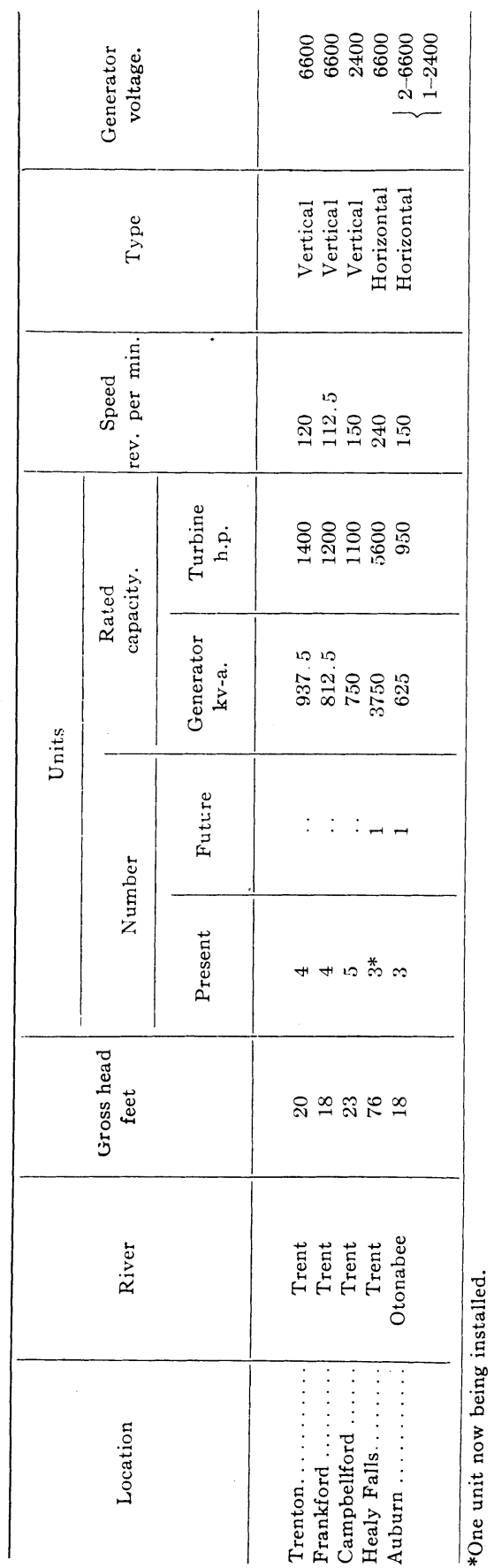


three-phase 60-cycle, 200 rev. per min. generators connected to two 700-h. p. turbines. These feed into the 44,000-volt net work of the Central Ontario system at Lindsay the voltage being stepped up in the generating station through two banks of transformers to 11,000 volts for transmission to Lindsay.

All these stations are on the route of the Trent Valley Canal, the dams having been constructed by the Government of the Dominion of Canada.

The Trenton station, known as Sidney Dam 2 development, being at Dam 2, section 1 of Trent Valley Canal, about one mile north of the Town of Trenton, was placed in operation by the Sidney Electric Power Co. in August 1911. The four generators feed into a single sectionalized bus, and two 6600volt feeders conduct the current to a transforming station across the road, which station also receives the output of the Frankford generating station at 6600 volts. Two $75-\mathrm{kw}$. 125 -volt exciter units are installed, one being a vertical turbinedriven unit and the other a motor-driven unit. Each of these exciters is capable of exciting all generators at 25 per cent overload with 65 per cent power factor current lagging.

The Frankford station, known as Sidney Dam 5 development, is located at Dam 5 on Section 1 of Trent Canal, about four miles north of Dam 2. This station was constructed by the Sidney Electric Power Company and placed in operation a short time after the Trenton station. It has a single unsectionalized 6600-volt bus and its entire output is fed over two 6600 -volt circuits to the transforming station at Dam 2 .

The Trenton transforming station contains three $3000-\mathrm{kv}-\mathrm{a}$, $6600 / 44,000$-volt, three-phase, 60 -cycle, shell-type transformers connected delta-star with ungrounded neutral, double hightension and low-tension buses, switching equipment for three 44,000 -volt lines and for six 6600 -volt lines.

The Campbellford station, known as the Stephen's Dam station, was first placed in operation in 1909 and is near Dam 1, Section 5 of Trent Valley Canal. This station contains four 1125-kv-a., three-phase, core-type, $2400 / 44,000$-volt transformers and two outgoing 44,000-volt line equipments. Excitation for the generators is obtained from two $60-\mathrm{kw}$. 125 -volt exciters, one turbine-driven and one motor-driven, with two $171 / 2-\mathrm{kw}$. belted exciters for emergency use. The station is situated some distance below the dam, the water being conducted to it through an open head race. 
The station at Healy. Falls is situated about seven miles above Campbellford. Water is conducted through steel penstocks from the head gates to the turbines. A long tail race excavation through rock was necessary and the enlargement of this tail race, necessitated by the installation of the third generator, is now being completed. This excavation work has been slow and difficult on account of the nature of the rock.

There are three 3750-kv-a., three-phase, shell-type, 6600/ 44,000 -volt transformers installed, with very flexible switching equipment consisting of double 6600 -volt buses, two 44,000 volt outgoing lines, a sectionalized 44,000-volt single transfer bus, with a transformer and an outgoing line forming a unit which may be operated independent of the bus. Provision is made for a fourth generator and transformer and for two additional high-tension line equipments. Excitation is provided by two 160-kw. 125-volt exciters, one being turbine-driven and one motor-driven.

The Auburn generating station is located in the north of Peterboro, on the Otonabee River $1200 \mathrm{ft}$. below the Auburn Dam. Water is taken to the turbines through an open head race $1200 \mathrm{ft}$. long paralleling the river. This station was built by the Auburn Power Co. and placed in operation in 1912 and no extensions have been made. The turbines are of the four runner type in open wheel pits $40 \mathrm{ft}$. long, $16 \mathrm{ft}$. wide and $14 \mathrm{ft}$. deep. A travelling steel gate $15 \mathrm{ft} .33 / 8$ in. by $14 \mathrm{ft} .3$ in. is provided with motor-driven lowering and hoisting mechanism. The gate is designed to be lowered against the running water in $21 / 2$ minutes. Two $90-\mathrm{kw}$., 125 -volt exciters, one being turbine driven and one motor-driven, furnish the excitation of this plant. One generator is wound for 2400 volts and feeds a section of the bus from which 2400 -volt feeders may be taken. This section of bus is connected to the 6600 -volt section of the bus through a bank of three 200-kv-a., 2400/6600-volt transformers. Feeders at 6600 volts, three-phase, connect this station to the transformer station adjacent which contains two $1875-\mathrm{kv}$-a., three-phase, core-type $6600 / 44,000$-volt transformers and one outgoing 44,000-volt line connecting into the 44,000 -volt net work of the Central Ontario System. Some power is also delivered to Peterboro at 6600 volts from the generating station.

The accompanying map, Fig. 1, and the diagram, Fig. 5, show the location of the generating stations of the Central 
Ontario System, and the extent of the transmission net work with substations. Other power sites along the Trent Valley Canal together with those described briefly above will, when developed, provide about 60,000 electrical $h$. p. with a maximum capacity of 75,000 electrical h.p. The present power output of the system is used for lighting, street railway and manufacturing purposes, a considerable quantity being required at Campbellford for a pulp and paper mill, and near Belleville for cement mills. All transmission lines are constructed on wood poles. The total mileage of 44,000 -volt circuits is 372 , with 15 miles of 11,000 -volt circuit, 16.4 miles of 6600 -volt circuits and 52 miles of 4000 volt circuits.

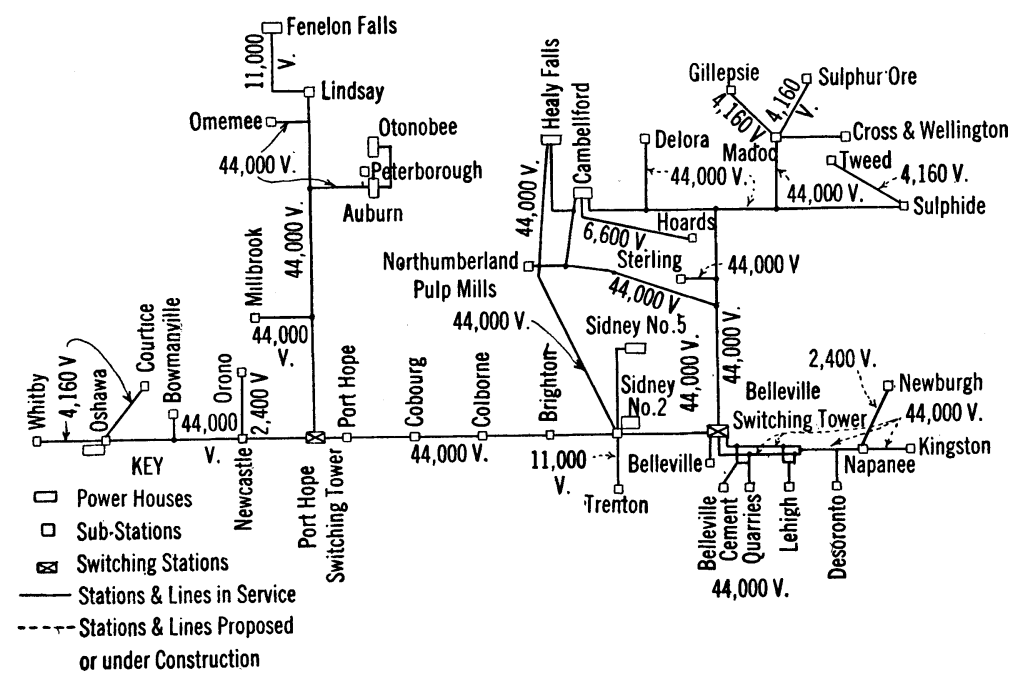

Fig. 5-Central Ontario System

\section{St. Lawrence System}

This system at the present time has no generating station owned by the Commission. Power is secured by contract from the hydraulic station of the M. F. Beach Company at Iroquois, but the amount obtainable proved inadequate and was supplemented by power obtained from the steam generating station of the town of Brockville. As additional power is needed arrangements are now being made to obtain an adequate supply from another source, near Cornwall. To take this power the Commission is now constructing a transforming station near Cornwall which will contain one bank of three $1250-\mathrm{kv}-\mathrm{a}$., single-phase, $63,500 / 26,400$-volt, 60 -cycle transformers connected 
star-delta and switching equipment for two incoming 110,000 volt circuits and for two outgoing 26,400-volt circuits.

This system now supplies power to Brockville, Prescott, Morrisburg, Winchester and Chesterville. Fig. 6 shows this system together with the Rideau system.

\section{Rideau System}

A new net work is being developed called the Rideau system and covering a district in the neighborhood of the Rideau River. Plans are now being prepared for a hydraulic generating station at High Falls on the Mississippi River near Clarendon, a point about 50 miles northerly from Kingston, Ontario. The

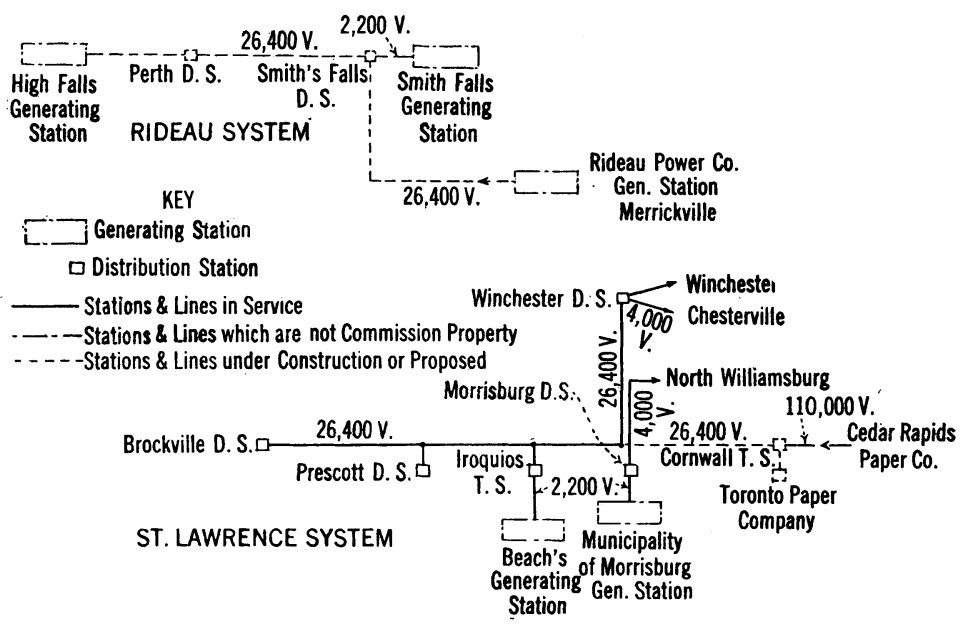

Fig. 6-St. Lawrence and Rideau Systems-60 Cycles

installation at this point will consist of four $350-\mathrm{kw} ., 2200$-volt, three-phase, 60-cycle, 300-rev. per min. horizontal generators connected to two turbines, one generator being at each end of turbine; and one $875-\mathrm{kv}$-a. 80 per cent power factor, threephase, 60-cycle, 2200-volt, 300-rev. per min. generator directconnected to its turbine with necessary switching and transformer equipment to transmit the full $2100-\mathrm{kw}$. output, at 26,400 volts to the Rideau system.

A portion of this system is now in operation, power being obtained at 26,400 volts, three-phase, 60 -cycles, under contract from the Rideau Power Co. at Merrickville, and transmitted to Smith Falls where at the substation the municipality's own 
generating stations are paralleled with this system on the lowtension bus.

This system may ultimately be connected with the St. Lawrence System.

\section{Niagara System}

The Niagara System comprises all lines and substations that receive power from Niagara Falls, and covers the entire district from Niagara River to the Detroit River and River St. Clair and north to Goderich and Harriston and east to Toronto. Power is received at a transformer station at Niagara Falls from the Ontario Power Co. (now controlled and operated by the Commission) and fom the Canadian Niagara PowerCompany, at 12,000 volts, three-phase, 25 cycles and is transformed to 110,000 volts and to 45,700 volts for transmission.

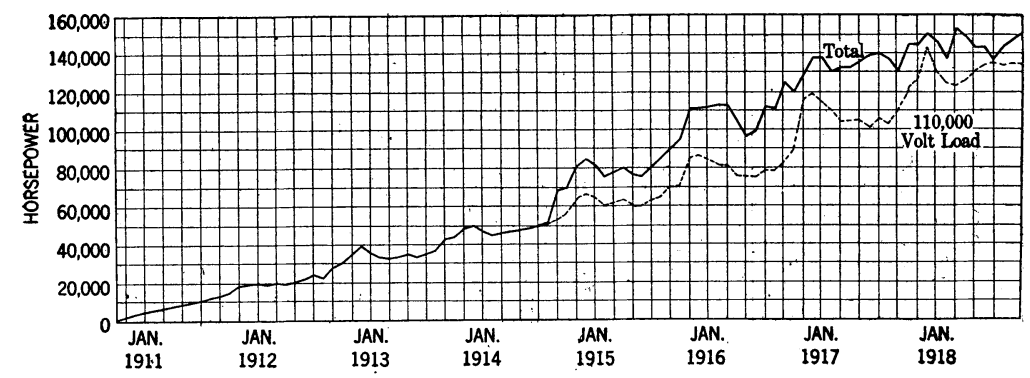

Fig. 9-Curve Showing Monthly Increase of Power Load of Municipalities Niagara System October 1910 to October 1918

There is now installed in the Niagara Transformer station $132,000 \mathrm{kv}$-a. of 110,000 -volt transfcrmers in eight banks and $42,000 \mathrm{kv}$-a. of 45,700 -volt transformers in four banks, not including spare units. Four banks of 110,000-volt units are composed of twelve 7500-kv-a., single-phase, shell-type 12,000/ 63,500-volt transformers, all other transformers being of 3500$\mathrm{kv}-\mathrm{a}$. rating. This station, in point of transformer capacity. is the largest in the world, having a total capacity of $174,000-\mathrm{kv}$-a, with $7000 \mathrm{kv}$-a. in spare units additional. Figs. 7 and 8 show two views of this Niagara transformer station.

Four outgoing 110,000-volt circuits feed to Dundas transformer and switching station and from there power is distributed to thirteen 110,000-volt transformer stations. Four 45,700-volt lines feed to Welland to the substations of the Electric Steel \& Metals Company, the Union Carbide Co. and 
PLATE III.

A. I. E. E.

VOL. XXXVIII, NO. 1

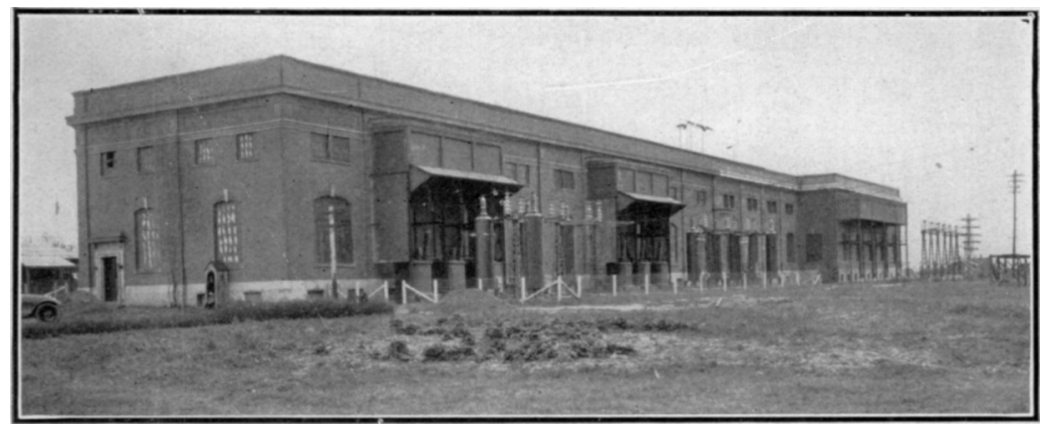

Fig. 7-View of Niagara Transformer Station Looking Southeast

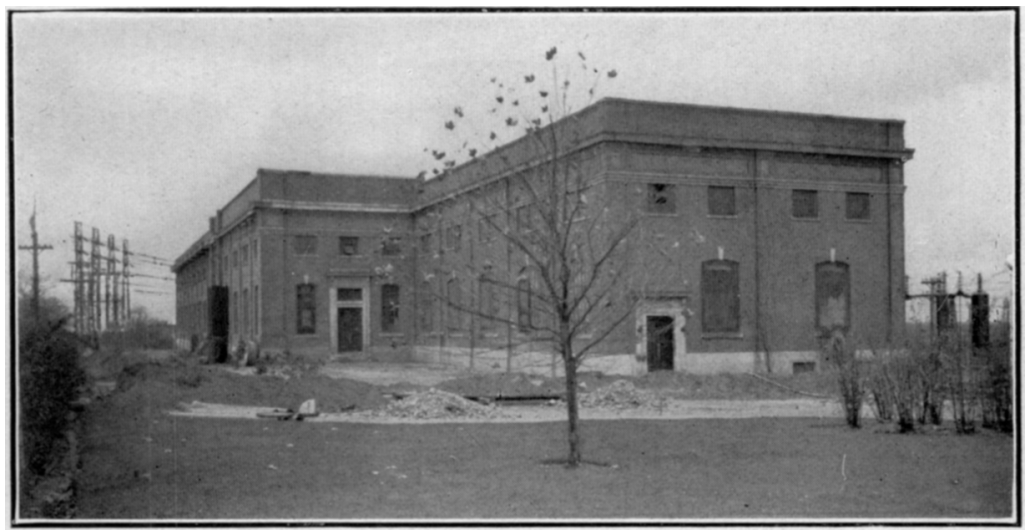

Fig. 8-View of Niagara Transformer Station Looking Southwest

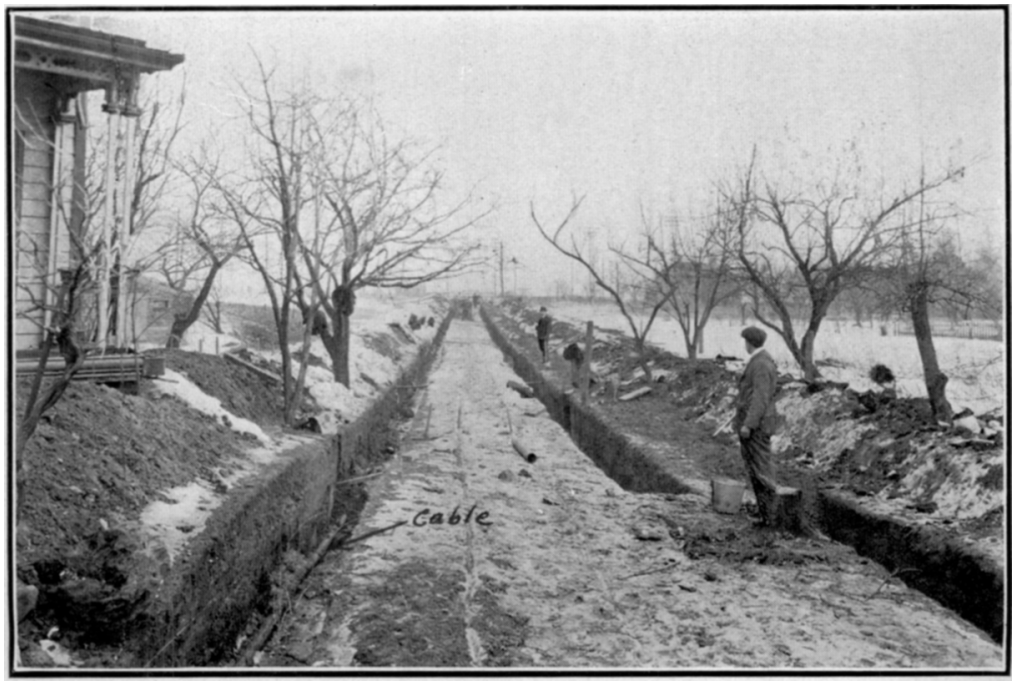



the city of Welland. From this latter point a single-circuit, 45,700-volt line runs to Dunnville.

This system was placed in operation in October 1910. The curve in Fig. 9 shows the monthly increase in power load of Municipalities on this System from October 1910 to October 1918. This gives some idea of the growth of the system in this period but the latter portion of the curve cannot be regarded as normal owing to the increase in power required for munitions

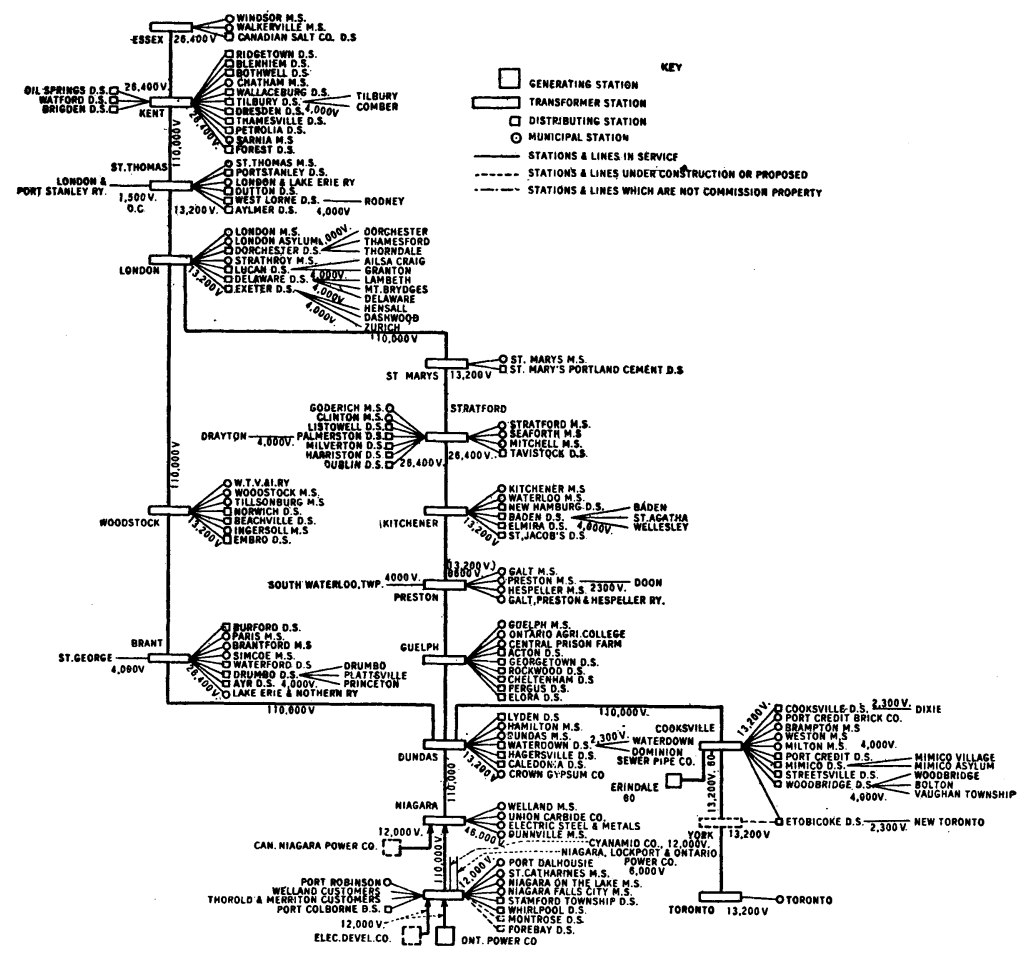

Fig. 10-Diagram of Stations-Niagara System

manufacture and the consequent restrictions on other uses to cut their requirements to a minimum.

The transmission net work, see Fig. 1 and Fig. 10, on this system contains 760 miles of 110,000 -volt circuits; 65 miles of 45,700 -volt circuits; 529 miles of 26,400 -volt circuits; 489 miles of 13,200 -volt circuits; 27 miles of 6600 -volt circuits; 180 miles of 4000 -volt circuits; and 20 miles of 2200 -volt circuits. The 110,000-volt and 45,700-volt circuits are carried on steel towers (with exception of one 45,700-volt line from Welland to Dunnville), while the 
other circuits mentioned above are standard wood pole line construction.

- The Commission early in 917 purchased the Erindale Power Company which had a hydraulic generating station on the Credit River at Erindale, 14 miles west of Toronto, containing two 600-kw. three-phase, 60-cycle, 13,200-volt, 200-rev. per min. generators, each direct-connected to a 1000-h. p. turbine designed for a $60-\mathrm{ft}$. head. The present operating head is about $50 \mathrm{ft}$. Water is carried from the dam to the power house through a $12 \mathrm{ft} .6$ in. diameter tunnel $900 \mathrm{ft}$. long. Two 60-kw. belted exciters furnish the excitation.

The output of this generating station is now transmitted to the Cooksville transformer station at 13,200 volts, 60 cycles, and is fed into the 13,200-volt, 25-cycle bus in that station through a $1000-\mathrm{kv}$-a. 60/25-cycle frequency changer set, augmenting the power supply on the Niagara system, and serving also to raise the power factor at the Cooksville station.

It is not the writer's intention to describe the plant of the Ontario Power Co. as descriptions of this plant have appeared in the A. I. E. E. Transactions (See Volume XXIV 1905, p. 807). Extensions to the plant have been made since then until, when the operation was taken over by the Commission in 1917, the generating station contained 14 generator units, generating 12,000-volt, three-phase, 25-cycle power with a total rating of $149,012-\mathrm{kv}-\mathrm{a}$. The original excitation scheme had been changed by the Ontario Power Company and a very complete description of this scheme as it now exists may be found in the Electric Journal Vol. 1914 p. 612 in article by Mr. J. A. Johnston. The distributing station of the Company contains the 12,000- 30,000- and 60,000-volt buses, the transformer banks and the outgoing line equipments and the control room for the plant. The switching scheme as originally laid out has been considerably re-arranged the buses being sectionalized and connected through reactors, these changes being due to the great amount of power generated and to the large proportion leaving the station at generator voltage.

The Commission, on behalf of the company, is now making extensions to the generating station. The building is being extended north about $90 \mathrm{ft}$. and a third pipe line of temporary nature consisting of wood stave pipe is being constructed. Two additional generating units are being installed each rated at $15,000 \mathrm{kv}$-a. maximum rating at 75 per cent power factor. 
These new generators are the same speed as the previous units namely $187.5 \mathrm{rev}$. per $\mathrm{min}$. and the frames are the same size as the $8775-\mathrm{kv}-\mathrm{a}$. units most recently installed. They have however a higher temperature guarantee and are so designed that they may be operated as synchronous condenser at zero power factor if it ever becomes necessary to remove them from this station. These generators were made in Canada, under war conditions, and all parts, except the laminated steel and the insulation, were produced in this country. This speaks well for Canadian industry in these trying times.

Each of these new units is excited by a 125-kw. 250-volt, motor-driven exciter, thus extending the excitation scheme referred to above.

The Ontario Power Company obtain some power from the Electrical Development Company's generating station at Niagara, this being brought into the distributing station on two incoming 12,000-volt feeders. When the present extensions to the distributing station are completed, there will be six main bus sections connected together through reactors. Three of these bus sections will supply the power delivered to the 12,000 volt bus in the Commission's transformer station to which the feeders from the Canadian Niagara Power Company are also connected through a bus reactor. The concentration of generator capacity on this 12,000 -volt bus is consequently very great and has necessitated material changes in the switching equipment and bus construction. The studies covering the installation of reactors on this 12,000-volt system have been most interesting. As these studies are still not fully completed, no diagram of the connections for the Ontario Power Company stations and the Commission's Niagara transformer station can be shown at this time. It will be sufficient to state that there is no 12,000-volt bus in the generating station, and that each generator feeds through an automatic oil circuit breaker in the generating station to its individual cables in the cable tunnels up the hill, thence to its group of circuit breakers in the distributing station where switching arrangement are such that each generator and each feeder may be connected to either of two bus sections. In the Commission's Niagara transformer station there is a single sectionalized 12,000-volt transfer bus system so arranged that feeders are connected through an auxiliary bus to the main bus or direct to a transformer bank.

It is of interest to note that the cables for the two new 15,000- 
$\mathrm{kv}$-a. generators were purchased after laboratory tests were made on manufacturers' samples to determine the dielectric losses and tendency of compound to flow, and guarantees on dielectric losses were obtained from the contractor.

Another interesting point in connection with the feeders entering the Commission's transformer station is that eight of these are three-conductor, armored cables laid directly in the earth without ducts. These armored cables all have sectorshaped conductors, with $8 / 32$-in. $\times 8 / 32$-in. paper insulation, a lead sheath and a double steel tape armor with jute bedding and jute covering. They are placed three feet below the surface and two and three feet apart center to center on private right of way. Where these buried cables cross ducts containing other cables, arrangements are provided to moisten the surrounding earth either by sprays above the surface or by porous tile in the ground. Figs. 11 and 12 show views of this armored cable installation, Fig. 10 showing the ventilating pipes at street crossing, the cables being in 6 -inch cast iron pipe across the street.

\section{The Queenston Development}

When the Commission in March 1908 contracted with the Ontario Power Company for 100,000 horse power, it was thought by many that such amount of power would meet the requirement for many years. This supply was however exhausted in 1915 that is, in 5 years from date of first delivery of power, and the additional power secured by arrangements with the Canadian Niagara Power Company has proved insufficient to meet the demands. It became necessary therefore to look to a new development to secure a further supply and the final decision was to proceed with a development called the Queenston Development which is authorized by an Act passed by Ontario Government in April 1917 called The Ontario Niagara Development Act.

Between Lakes Erie and Ontario there is a difference in elevation of 330 feet. The greatest net head now utilized on the Canadian side at Niagara Falls is about $160 \mathrm{ft}$. Canada is entitled to divert $36,000 \mathrm{cu}$. ft. per second from the Niagara River, and of this amount, by an Ontario Government Order in Council in 1915, the Commission were allotted $6610 \mathrm{cu}$. ft. per second. The Ontario Power Company were allotted 11,180 cu. ft. per second, so that, within the control of the Commission, there is now available $17,799 \mathrm{cu}$. ft. per second. 
PLATE IV

A. I. E. E.

VOL. XXXVIII, NO. 1

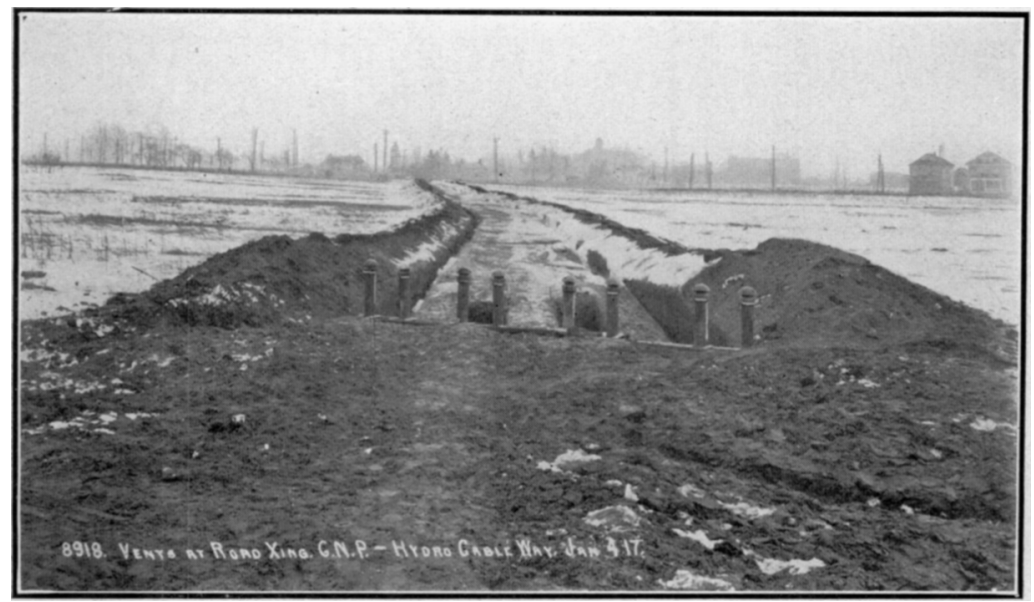

Fig. 12-Armored Cable Installation

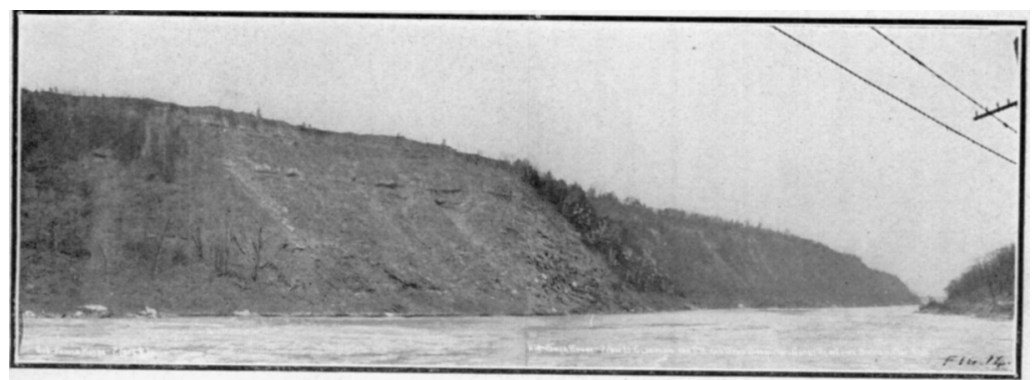

Fig. 14-Queenstown Power House Site [HULL] 

PLATE $V$

A. I. E. E.

VOL. XXXVIII, NO. 1

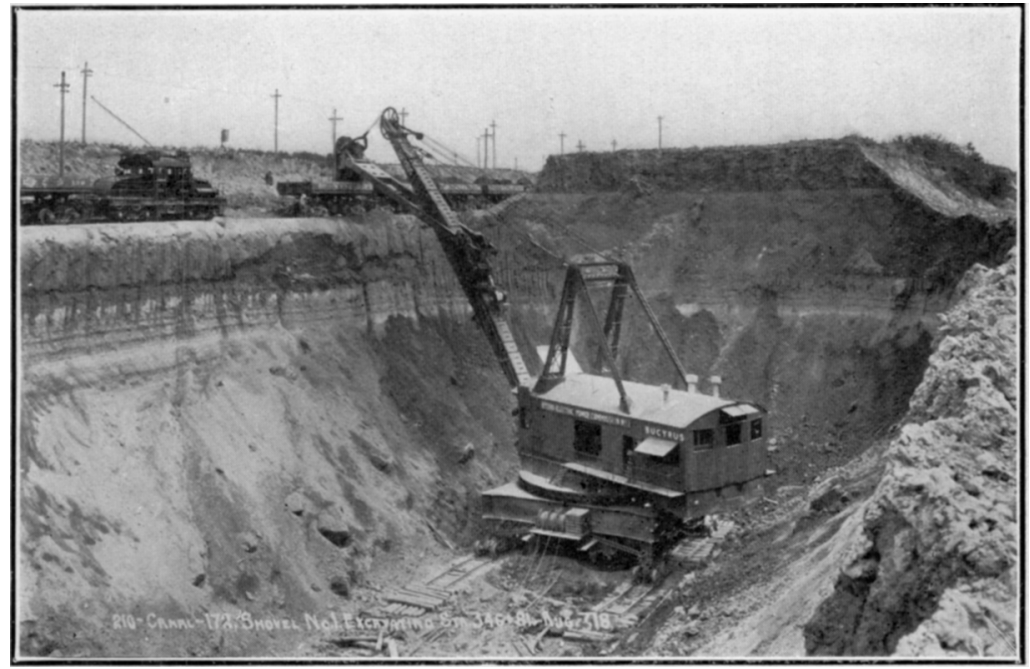

Fig. 15-Large Electric Shovel

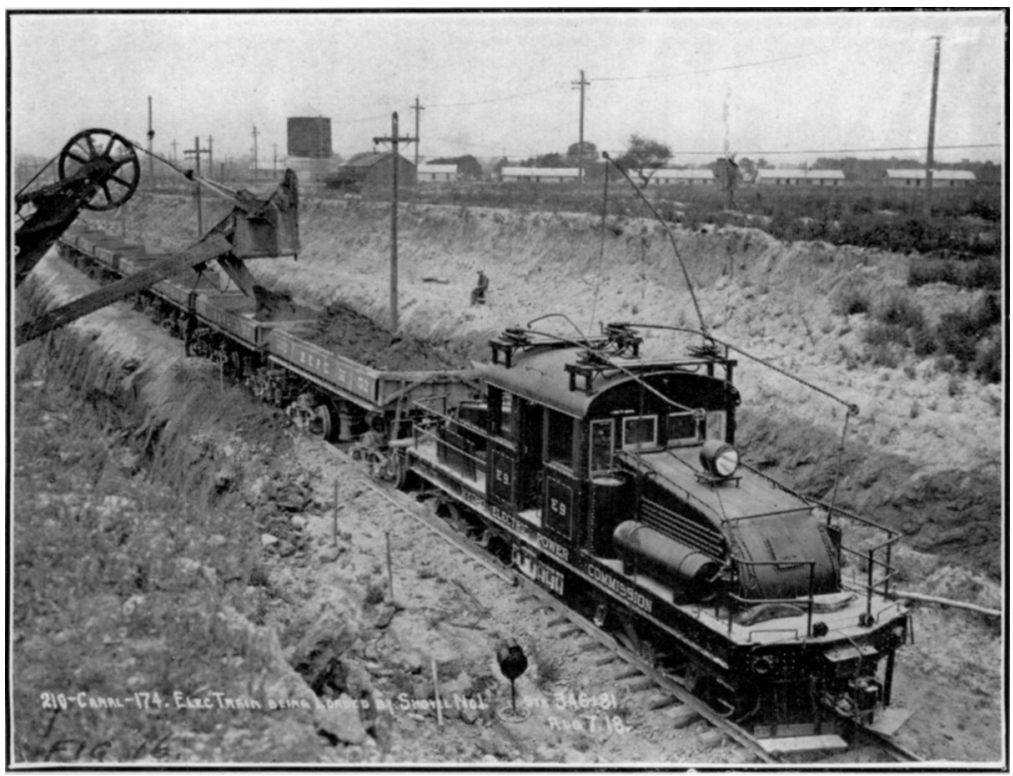

Fig. 16-Electric Locomotive and Dump Cars [huld] 

To obtain the greatest amount of power from the water available, after careful surveys and studies, it was decided to locate the generating station just above Queenston, and to take water from the Niagara River, through the Welland River (reversing the flow in same) and canals encircling the City of Niagara Falls to Queenston. The first canal is now under construction and the accompanying map of the Niagara District, shows its location. Fig. 13 shows a general plan of this scheme.

The total length of waterway from the Niagara River to the generating station site is about $12 \frac{1}{2}$ miles, $4 \frac{1}{4}$ miles of this

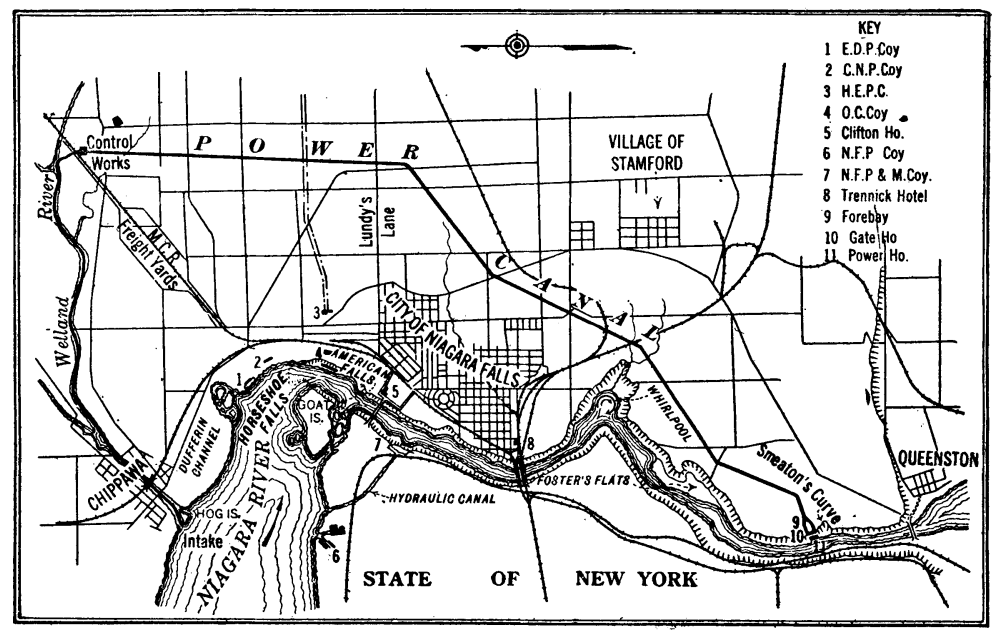

Fig. 13-General Plan of Niagara Power Development-HydroElectric Power Commission

distance being in the Welland River, and the balance in an excavated canal. The net effective head will be about $305 \mathrm{ft}$. and the first canal is normally designed for $10,000 \mathrm{cu}$. $\mathrm{ft}$. per second at minimum low water.

The generating station will be located about one mile up stream from Queenston, in the Gorge just at the end of the last rapids in the river. At this point the banks are steep and short penstocks only will be required. Provision is being made for extensions, and right-of-way for two additional canals has been purchased. Fig. 14 shows a view of power house site.

To show the effect of utilizing the greatest possible head of water, it may be pointed out that about $30 \mathrm{~h}$. p. will be 
developed for each cubic foot per second in this development, whereas about $14 \mathrm{~h}$. p. is all that is obtained in existing plants at Niagara Falls.

The development now under construction is designed as regards canal, forebay, gate house sub-structure and power house substructure, for a capacity of 300,000 h. p. It is proposed to construct the gatehouse and power house superstructure for an initial installation of $200,000 \mathrm{~h}$. p. in four units. The designs are made so that extensions of power house and gate house can be made to almost any extent. Future plans contemplate the use of $100,000-\mathrm{h}$. p. units.

The turbine speed has been fixed at 187.5 rev. per min. and specification for the generators are now being issued calling for 45,000-kv-a., 85 per cent power factor, 12,000-volt, threephase, maximum-rated generators of vertical type equipped with thrust bearings to take the weight of the rotating part of the generator plus the downward thrust of the turbines. Directconnected exciter mounted above the thrust bearings are proposed. The generators will be liberally equipped with embedded temperature detectors so that close and accurate observations may be kept of operating temperatures. The specified maximum temperature of any part of the generator at rated load is 100 deg. cent. with cooling air at 40 deg. cent. The ventilation problem for such units is of great importance, each unit requiring approximately $125,000 \mathrm{cu}$. $\mathrm{ft}$. of air per minute. Plans for the switching equipment and transforming equipment are now being developed and as they are not in final form, it is not opportune to give any detail description. It is proposed to install double 12,000-volt sectionalized buses, banks of transformers consisting of three $15,000-\mathrm{kv}-\mathrm{a}$., single-phase units, and to lay out the switching equipment so that one generator, one bank of transformers, and one outgoing high-tension line will be a unit. Bus tie reactors will be provided, and the shortcircuit current will be limited to a value that can safely be handled on the circuits and circuit breakers.

It is proposed to install two small service generators to supply power required for the station services such as pumping, cranes, lighting, machine shop, ventilating, etc.

To carry on the construction work on this development it was decided to make an extensive use of electric power as possible. Two large electrically operated revolving shovels each fitted with an eight-cu. yd. bucket for earth excavation and of capacity 
to handle a five-ton bucket in rock were provided. See Fig. 15. The larger of these two shovels has a boom $90 \mathrm{ft}$. long and a dipper stick $80 \mathrm{ft}$. long, while the smaller shovel has a boom $80 \mathrm{ft}$. long and a dipper stick $58 \mathrm{ft}$. long. Each shovel has motors of a nominal total rating of $715 \mathrm{~h}$. p. on a half hour rating. Three shovels weigh over 300 tons each and have a capacity of 5000 cu. yd. of earth per day. Five other electrically operated shovels are also provided having bucket capacities ranging from $7 / 8$ to $41 / 2$ cu. yd.

The railway equipment of the construction work includes 150 dump cars of $20 \mathrm{cu}$. yd. capacity each, six 40 -ton steam locomotives and twelve 50-ton electric locomotives, as shown in Fig. 16.

The electric power required for shovels, trains, air compressors etc., is obtained from the Ontario Power Company's station and is transmitted over two overhead feeders to the Whirlpool Substation located near the Whirlpool. A similar substation will shortly be erected near Montrose on the southerly section of the canal. The Whirlpool stibstation is of semi-permanent construction and contains switching equipment for the two 12,000 -volt incoming lines, and for three 1500-kv-a., 12,000/4000volt transformers, four $500-\mathrm{kw}$. 600-volt, d-c. synchronous converters with their 12,000-volt transformers. An adjoining room contains eight air compressors of $1000 \mathrm{cu}$. ft. per minute capacity each against $125 \mathrm{lb}$. pressure, belt driven from 550 -volt motors, supplied through two banks of $200-\mathrm{kv}-\mathrm{a}$., 2300/550volt transformers. Air is distributed up and down the canal for a distance of three miles from this substation to operate rock drills, channellers and forges, etc.

Power is distributed up and down the canal by 4000 -volt, 25-cycle, three-phase, four-wire, grounded-neutral circuits to which the shovels are connected through flexible armored cable. A double track railway has been built for the full length of the canal with a branch to the main dumping point at St. Davids. These railway lines are electrified, the trolley wires being offset to one side of the track so as not to interfere with the shovels.

The substation at Montrose will be identical with that at Whirlpool and it will similarly serve to supply power for the work on the upper end of the canal.

The extensive use of electric power on the construction of works of the magnitude of this development is working out well and is resulting in a great saving of coal. 
The enormous amount of power to be transmitted from this Queenston development involves much engineering study to work out a solution particularly when it is borne in mind that a large amount of capital is invested in existing stations and lines operating at 110,000 volts. These studies are now under way and it is to be hoped that at some later date, there will be placed before the Institute a more complete description of this Queenston Development. and its transmission lines connecting in to the Commission's Niagara System.

For those who wish further information on the subject of electric power generation in Ontario, reference may be made to the following:

1. Annual Reports of Hydro Electric Power Commission of Ontario from 1908 to date.

2. The Power Commission Act with Amendments-Ontario Government.

3. Report of Commission of Conservation, Canada, on "Water Powers of Canada" 1911, also 8th Annual Report (1917) of this Commission.

4. Report of Dominion Water Power Branch (Canada) on "Water Powers of Canada."

5. Volumes of "Canadian Engineer" Toronto.

6. Volumes of "Electrical News" Toronto.

7. Transactions of Canadian Society of Civil Engineers, (now the Engineering Institute of Canada. 